\title{
Effect of tourism-generated wastewater on biogenic ions concentrations in stream water in Tatra National Park (Poland)
}

\author{
Joanna Paulina Siwek \& Wojciech Biernacki
}

Keywords: tourism-generated wastewater, stream water quality, water protection, biogenic ions, alpine environment, Tatra National Park

\section{Abstract}

The purpose of the research conducted in the years 2008-2009 was to determine the effect of wastewater generated by several tourist lodges in Tatra National Park (an alpine environment) on the concentration of biogenic ions $\left(\mathrm{NH}_{4}^{+}, \mathrm{NO}_{2}^{-}, \mathrm{NO}_{3}\right.$ and $\mathrm{PO}_{4}{ }^{3-}$ ) in local streams into which the wastewater was being discharged. Wastewater discharged from mechanical biological wastewater treatment plants operated by tourist lodges usually has high concentrations of $\mathrm{NH}_{4}{ }^{+}$and $\mathrm{PO}_{4}{ }^{3-}$. The largest loads of biogenic ions were discharged into streams during the tourist season from May until September. Although the dilution conditions were good, the concentrations of some forms of biogenic ions in streams were significantly higher at points tens of metres downstream from the point of discharge than at points located upstream from the point of discharge. The concentrations of $\mathrm{NH}_{4}{ }^{+}$and $\mathrm{PO}_{4}{ }^{3-}$ ions increased significantly in streams into which wastewater was being discharged from wastewater treatment plants in Tatra National Park (NP). Concentrations of $\mathrm{NO}_{3}{ }^{-}$increased in the case of a stream into which untreated wastewater was being discharged after flowing down a mountain couloir for several hundred metres in the Tatras.

The water and sewer management situation in Tatra NP has improved significantly since the time when this research was conducted. Poland's entry into the European Union in 2005 made additional EU funding available to be invested in various environmental projects. Most existing wastewater treatment plants were fully modernized in the years 2010-2011, and new plants were built where none had been. Even so, it seems that transporting wastewater to treatment plants outside the national park is the most effective and reliable method of protecting the oligotrophic mountain waters of the Tatras from pollution.
Profile

Protected area

Tatra National Park

Mountain range

Carpathians

Country

Poland

\section{Introduction}

The $20^{\text {th }}$ century saw a rapid increase in tourist activities in protected natural areas (Eagles \& McCool 2002). For example, the number of tourists at U.S. national parks rose from just a handful in 1872 to nearly 65 million in 2010 (U.S. National Park Service 2012). As tourist traffic increased, human impact on the natural environment in protected areas intensified. Although examples of the positive impact of tourism on the natural environment do exist - in some areas residents have participated in tourism and given up hunting (Eagles et al. 2002; Li et al. 2006), most impact is generally negative. This fact is confirmed by numerous cases of research on various elements of the natural environment conducted in protected areas. The works of Sun \& Walsh (1998) and Cilimburg et al. (2000) contain a review of a rich selection of examples of such research.

Tatra NP was established in southern Poland in 1954 to help preserve the natural environment of the high mountain range. In 1993 Tatra NP, together with its sister national park located across the border in Slovakia, formed the Tatra Biosphere Reserve under UN-

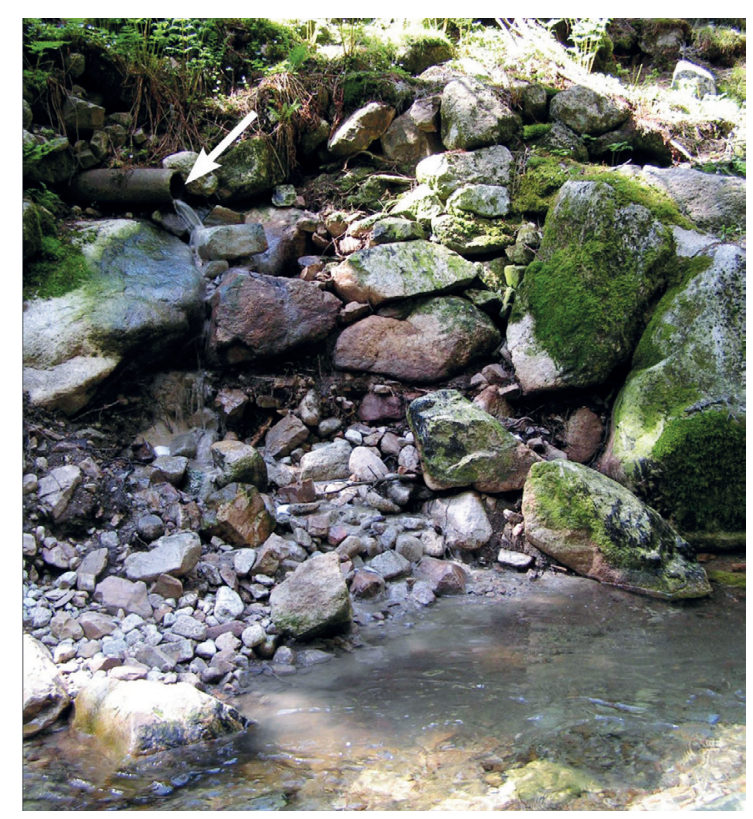

Figure 1 - Wastewater produced by tourist lodges in the Tatra Mountains causes significant changes in the water quality of the streams into which it is discharged. Photograph shows disposal of wastewater from Murowaniec Tourist Lodge into Sucha Woda Creek. (C) J.P. Siwek 


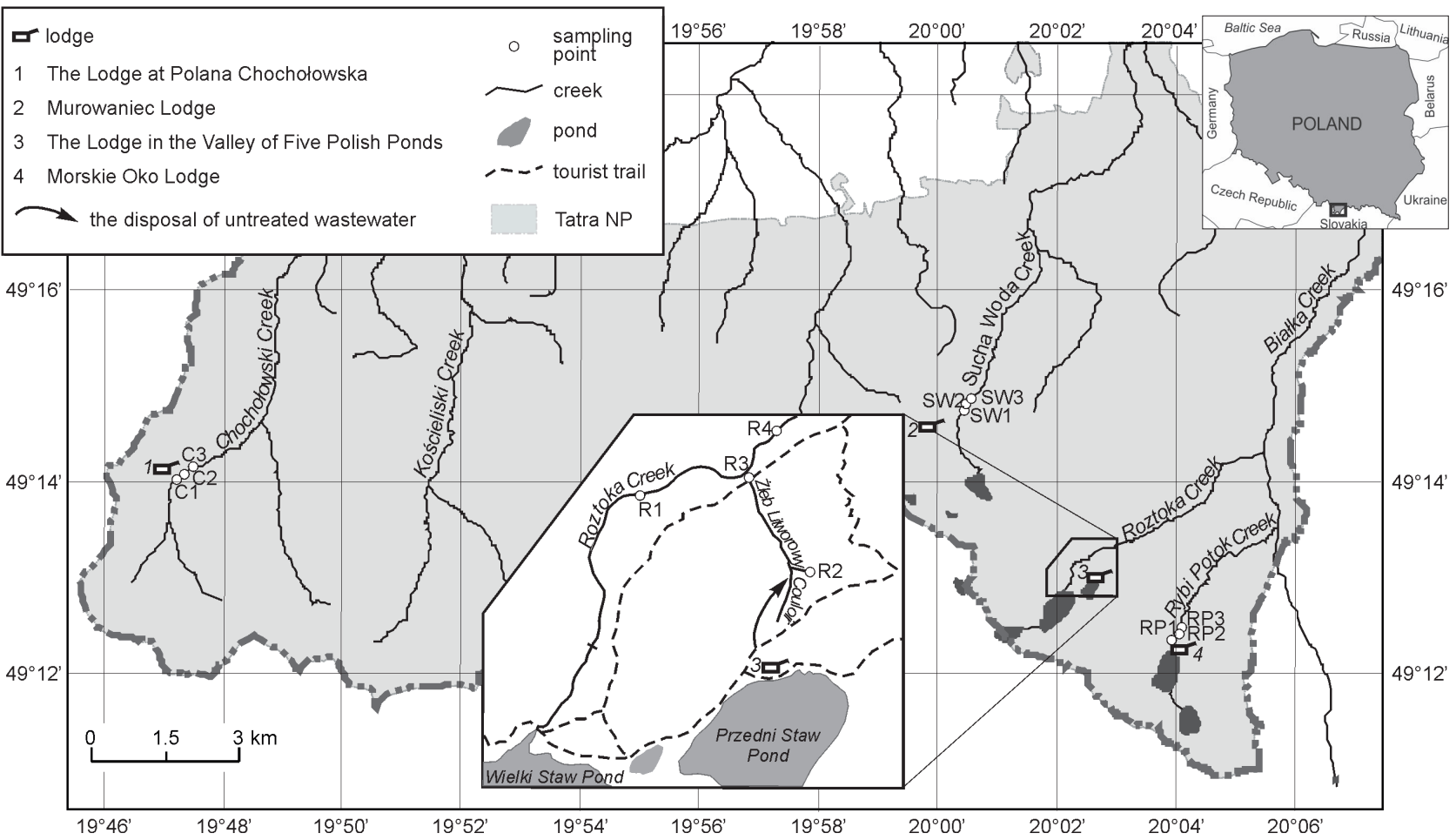

Figure 2 - Study area (symbols of sampling points as in Table 1). Data source: Head Office of Geodesy and Cartography in Poland.

ESCO's Man and the Biosphere programme. Tatra NP has always been especially popular with tourists and its popularity has increased from year to year since its foundation. Zakopane, the largest tourist town in the Polish Tatra Mountains, was visited by 150000 tourists in 1948. By 1962 the number of tourists exceeded one million. In 1978 the number of tourists who visited Zakopane reached a record 3.6 million (Mirek 1996). For the last two decades Tatra NP's visitor numbers have remained at about 2.5 million (Tatra NP 2012). The impact of tourist traffic on Tatra NP natural environment is many times larger than that in other mountain national parks in Europe. For example, more recent figures for Berchtesgaden NP (Germany) are 57000 tourists per hectare per year; next are Swiss NP and Hohe Tauern NP (Austria), both with 9000, and 120000 visitors / ha / year for Tatra NP (Kurek 2007).

Water quality is a good indicator of the quality of the natural environment, as water collects and subsequently distributes various types of pollutants (Siwek et al. 2013). Earlier research conducted in protected areas indicates that the impact of tourist-related activities on the water environment changes water chemistry (Silsbee \& Larson 1982a; Pickering et al. 2003), water bacterial content (Varness et al. 1978; Silsbee \& Larson 1982b; Cilimburg et al. 2000; McDonald et al. 2008; Ells \& Monz 2011), the trophic state of water (Flack et al. 1988) and the ecological state of water (Kawecka 1993). However, the impact of tourist-generated wastewater on the water quality of the stream into which the wastewater is discharged is still poorly documented.

The pollution of waters with wastewater discharged from tourist lodges is a problem that exists in many mountain areas protected by law - and in some of them it has a long history. For example, in the Alps it was not until the 1980s that tourist mountain lodges were equipped with simple mechanical treatment devices such as septic tanks - while infiltration of raw sewage and dispersion of untreated solids in the environment were methods used before 1980s. It was not until the year 2000 that buildings which produce wastewater were required to have a biological wastewater treatment plant (Rauch \& Becker 2000). An improvement in water and sewage management in mountain areas in member states of the European Union occurred when the Water Framework Directive (2000) was put into effect. Its main goal was the protection and quality improvement of inland surface waters in the European Union. Biological wastewater treatment plants were built at many mountain lodges thanks to financial support received from the European Union. For example, in the years 1998-2002, 15 treatment plants were built in the Austrian Alps as a part of Life-Project support (Life98 ENV/A/000547 2000). Countries that joined the EU in 2005, such as Poland and Slovakia, were required to comply with the regulations of the Water Framework Directive (2000). However, it was not until after 2010 that water and wastewater management in mountain areas like the Tatra Mountains really improved (Ladygin 2011).

The problem of water pollution by anthropogenic wastewater in the Tatra Mountains is especially important because of the oligotrophic nature of water in the area. The mineral content of stream water in the crystalline part of the Tatra Mountains does not exceed several dozen $\mathrm{mg} / \mathrm{L}$, and in the sedimentary part, 
Table 1 - Characteristics of sampling sites (location as in Figure 2).

\begin{tabular}{|c|c|c|c|}
\hline Catchment & Symbol & Body of water/wastewater & Sampling site characteristic \\
\hline \multirow{3}{*}{$\begin{array}{l}\text { Chochołowski } \\
\text { Creek }\end{array}$} & $\mathrm{Cl}$ & Chochołowski Creek & upstream of wastewater discharge site \\
\hline & $\mathrm{C} 2$ & wastewater & $\begin{array}{l}\text { sewage from wastewater treatment plant operated by Polana Chochołowska } \\
\text { tourist lodge }\end{array}$ \\
\hline & C3 & Chochołowski Creek & downstream of wastewater discharge site \\
\hline \multirow{3}{*}{$\begin{array}{l}\text { Sucha Woda } \\
\text { Creek }\end{array}$} & SW1 & Sucha Woda Creek & upstream of wastewater discharge site \\
\hline & SW2 & wastewater & sewage from wastewater treatment plant operated by Murowaniec tourist lodge \\
\hline & SW3 & Sucha Woda Creek & downstream of wastewater discharge site \\
\hline \multirow{4}{*}{ Roztoka Creek } & R1 & Roztoka Creek & upstream of wastewater discharge site \\
\hline & R2 & $\begin{array}{l}\text { water discharged from the } \\
\text { HPS }\end{array}$ & Przedni Staw Pond is a source of water for the HPS \\
\hline & R3 & Zleb Litworowy Couloir & water samples were collected at the mouth of the Zleb Litworowy Couloir \\
\hline & R4 & Roztoka Creek & downstream of wastewater discharge site \\
\hline \multirow{3}{*}{$\begin{array}{l}\text { Rybi Potok } \\
\text { Creek }\end{array}$} & RP1 & Rybi Potok Creek & upstream of wastewater discharge site \\
\hline & RP2 & wastewater & sewage from wastewater treatment plant operated by Morskie Oko tourist lodge \\
\hline & RP3 & Rybi Potok Creek & downstream of wastewater discharge site \\
\hline
\end{tabular}

mineral content usually does not exceed $300 \mathrm{mg} / \mathrm{L}$ (Oleksynowa \& Komornicki 1996; Żelazny 2012). Hydrobiological research conducted in the 1970s indicates that even a small change in the trophic state of streams in the Tatras causes observable changes in the living conditions of organisms inhabiting the streams. Consequently, such changes will amount to a key change in the region's ecological system (Kawecka 1977; Kownacki 1977).

The purpose of this study was to determine the effect of wastewater generated by several popular tourist lodges in Tatra NP in southern Poland on the concentration of biogenic ions in local streams into which the wastewater was being discharged. Biogenic ions are responsible for the eutrophication of bodies of water and consequently their pollution (Allan 1995). The research aimed to answer the following questions: 1. What is the concentration of biogenic ions $\left(\mathrm{NH}_{4}^{+}\right.$, $\mathrm{NO}_{2}^{-}, \mathrm{NO}_{3}{ }^{-}, \mathrm{PO}_{4}{ }^{3-}$ ) in wastewater discharged into streams in the Tatra Mountains? What loads of biogenic ions enter streams in the Tatra Mountains along with wastewater?

2. What is the concentration of biogenic ions in local streams at points upstream and downstream from the point where wastewater is discharged? Are these differences statistically significant?

3. Are changes in tourist numbers reflected in the quantity of biogenic ions supplied to streams along with wastewater over the course of a year?

\section{Study area}

The research study was conducted in the Polish part of the Tatra Mountains, which is protected as Tatra National Park. The Tatra Mountains are young alpine-type mountains and are the highest mountain range of the Carpathians. The highest summit within Tatra NP is Mount Rysy (2 499 m.a.s.l.).

The research study focused on the following four streams: Potok Chochołowski Creek, Sucha Woda Creek, Rybi Potok Creek and Roztoka Creek (Fig- ure 2). The streams are characterized by flow values that vary over the course of the year. High discharge values are noted during late winter and spring snow melts and with summer thunderstorms. Stream runoff decreases sharply in winter, as freezing temperatures stop the flow for the most part (Lajczak 1996). Wastewater from the tourist lodges Polana Chochołowska Lodge, Murowaniec Lodge, Morskie Oko Lodge and the lodge in the Valley of Five Polish Ponds is discharged into the four streams. Mechanical biological wastewater treatment plants are operated by tourist lodges at Chochołowska Polana, Morskie Oko and Murowaniec. The lodge in the Valley of Five Polish Ponds was the only lodge in Tatra NP which did not have its own wastewater treatment plant at the time when the research was conducted. A septic tank was the only system for the disposal of wastewater available, although it looked like it was leaking (personal observation, 2008 / 2009).

\section{Materials and methods}

This research was conducted from July 2008 to June 2009. Wastewater samples and stream water samples were usually collected once a month for chemical analysis. The stream water samples were collected at a distance of several tens of metres upstream from the wastewater discharge site and several tens of metres downstream from that point (Table 1). A similar methodology was used by Bombówna (1977), Starzecka (1977), Kawecka (1977), and Kownacki (1977) in the Tatras (Poland), and by Varness et al. (1978) in the Cascade Range (USA). Stream water samples were collected at locations where wastewater and stream water were already well mixed. The degree of mixing of wastewater with stream water was checked by measuring the electrical conductivity of water in each stream. The measurements were performed at several, usually fewer than twenty, points along a selected crosssection of each given stream channel. If the electrical conductivity values were the same along the entire 
Table 2 - Statistical characteristics of discharge $Q\left(\mathrm{dm}^{3} / \mathrm{s}\right)$ and biogenic ion concentrations $\left(\mathrm{mg} / \mathrm{dm}^{3}\right)$ in wastewater generated by tourist lodges in Tatra NP; $<D L$ : below the detection limit.

\begin{tabular}{|c|c|c|c|c|c|}
\hline \multirow[b]{2}{*}{$\begin{array}{l}\text { Tourist lodge } \\
\text { name }\end{array}$} & $\mathbf{Q}$ & $\mathrm{NH}_{4}^{+}$ & $\mathrm{NO}_{2}^{-}$ & $\mathrm{NO}_{3}^{-}$ & $\mathrm{PO}_{4}{ }^{3-}$ \\
\hline & \multicolumn{5}{|c|}{$\begin{array}{c}\text { mean } \\
\text { min-max } \\
\text { variation coefficient }\end{array}$} \\
\hline $\begin{array}{l}\text { Polana } \\
\text { Chochołowska }\end{array}$ & $\begin{array}{r}0.39 \\
0.15-0.75 \\
0.50 \\
\end{array}$ & $\begin{array}{r}18.72 \\
0.19-49.89 \\
0.95\end{array}$ & $\begin{array}{r}1.23 \\
<\mathrm{DL}-10.11 \\
2.32\end{array}$ & $\begin{array}{r}8.45 \\
<\mathrm{DL}-41.64 \\
1.36\end{array}$ & $\begin{array}{r}3.77 \\
0.64-9.51 \\
0.81\end{array}$ \\
\hline Murowaniec & \begin{tabular}{r|}
0.98 \\
$0.02-2.70$ \\
1.01
\end{tabular} & $\begin{array}{r}63.09 \\
5.50-149.26 \\
0.80 \\
\end{array}$ & $\begin{array}{r}0.02 \\
<\mathrm{DL}-0.20 \\
3.00\end{array}$ & $\begin{array}{r}0.41 \\
<\mathrm{DL}-2.74 \\
2.20\end{array}$ & $\begin{array}{r}14.32 \\
1.37-34.08 \\
0.72\end{array}$ \\
\hline Morskie Oko & $\begin{array}{r}0.18 \\
0.01-0.85 \\
1.89\end{array}$ & $\begin{array}{r}0.78 \\
0.01-2.28 \\
1.15\end{array}$ & $\begin{array}{r}1.44 \\
0.004-7.75 \\
1.82\end{array}$ & $\begin{array}{r}5.55 \\
1.23-13.64 \\
0.89\end{array}$ & $\begin{array}{r}0.96 \\
0.05-2.82 \\
1.25\end{array}$ \\
\hline
\end{tabular}

cross-section (over the entire stream width), then it was judged to mean that the water was mixed well.

Wastewater produced at the lodge in the Valley of Five Polish Ponds, which was the one without a wastewater treatment plant at the time when this research was conducted, was being discharged into the upstream section of the Żleb Litworowy Couloir, a large naturally formed narrow mountain gully. The wastewater initially discharged into the natural gutter, forming a small intermittent stream, and then it joined the water discharged from a small hydroelectric power station operated at the lodge. This created a stream that contained wastewater that later flowed into Roztoka Creek (Figure 2). Wastewater samples were not collected in the upper part of the Żleb Litworowy Couloir, as it was practically inaccessible. However, water samples were collected at the mouth of the Żleb Litworowy Couloir. Water samples were also collected from the water discharged from the lodge's hydroelectric power station. On average, about $55 \%$ of waters flowing out of the Żleb Litworowy Couloir were waters discharged from the hydroelectric power station. In addition, water samples were collected from Rozto$\mathrm{ka}$ Creek at points upstream and downstream from the mouth of the Żleb Litworowy Couloir (Figure 2).

The collection of wastewater and stream water samples was coupled with stream water level measurements and measurements of wastewater flow using the volumetric method. Discharge was measured several times in every tested stream using a SEBA HYDROMETRY M1 Universal Current Meter. Concentrations of biogenic ions $\left(\mathrm{NH}_{4}^{+}, \mathrm{NO}_{2}^{-}, \mathrm{NO}_{3}^{-}, \mathrm{PO}_{4}{ }^{3-}\right.$ ) were determined using a DIONEX ICS 2000 ion chromatograph at the Hydrochemical Laboratory of the Jagiellonian University's Institute of Geography and Spatial Management in Kraków. The limits of detection for measuring the concentrations of specific biogenic ions were: $0.005 \mathrm{mg} / \mathrm{L}$ for $\mathrm{NH}_{4}^{+}, 0.0025 \mathrm{mg} / \mathrm{L}$ for $\mathrm{NO}_{2}{ }^{-}, 0.0025 \mathrm{mg} / \mathrm{L}$ for $\mathrm{NO}_{3}{ }^{-}, 0.01 \mathrm{mg} / \mathrm{L}$ for $\mathrm{PO}_{4}{ }^{3-}$. In cases when the concentration of some ion did not reach the limit of detection, a value equal to $75 \%$ of the value of the limit of detection was accepted for statistical computation purposes.
The significance of differences in the concentrations of selected forms of biogenic ions in stream water at points upstream and downstream from a wastewater discharge site was evaluated via the nonparametric Wilcoxon signed-rank test (paired difference test) using Statistica 10 software.

Statistical data on the number of tourists who visited Tatra NP were obtained online from Tatra NP (2012).

\section{Results}

Polana Chochołowska Lodge in the catchment of Potok Chochołowski Creek

Polana Chochołowska Lodge was found to discharge, on average, $0.39 \mathrm{~L} / \mathrm{s}$ of wastewater into Potok Chocholowski Creek. The wastewater from Polana Chochołowska Lodge had high concentrations of all biogenic ions, especially $\mathrm{NH}_{4}{ }^{+}, \mathrm{NO}_{2}^{-}$, and $\mathrm{PO}_{4}{ }^{3-}$ (Table 2). The largest loads of $\mathrm{NH}_{4}^{+}$and $\mathrm{PO}_{4}^{3-}$ were supplied to Potok Chochołowski Creek during the tourist season in the summer months (Figure 3). It was a time of relatively low discharge in Potok Chochołowski Creek, such as in August and September (Figure 3). The wastewater produced by Polana Chochołowska Lodge showed the least distinct changes in the quality and quantity over the course of the year. This was confirmed by values of the variability coefficient for this lodge, which were lower than those for the remaining tourist lodges studied (Table 2). This was related to smaller variability in tourist traffic over the course of the year (Figure 3), as the lodge at Polana Chochołowska is easily accessible even in winter. It is a popular tourist destination year-round.

The effect of wastewater on the concentrations of biogenic ions in Chochołowski Potok Creek was statistically significant in the case of $\mathrm{NH}_{4}^{+}, \mathrm{NO}_{2}^{-}$, and $\mathrm{PO}_{4}{ }^{3-}$ ions (Table 3). The concentrations of the three ions in Chochołowski Potok Creek upstream from the point where the wastewater was discharged usually did not exceed the limit of detection specific to the measurement devices used. This means that the concentrations of the three ions were close to zero. However, several tens of metres downstream from the point of discharge, the three concentrations were almost always detectable and their maximums reached: 0.85, 0.07, and $0.23 \mathrm{mg} / \mathrm{L}$, respectively (Figure 4).

\section{Murowaniec Lodge in the catchment of Sucha Woda Creek}

Murowaniec Lodge was discharging wastewater at an average rate of $0.98 \mathrm{~L} / \mathrm{s}$ (almost $85 \mathrm{~m}^{3}$ in a 24-hour period) into Sucha Woda Creek in the years 2008-2009 (Figure 4). The wastewater produced by Murowaniec was marked by very high concentrations of $\mathrm{NH}_{4}^{+}$and $\mathrm{PO}_{4}{ }^{3-}$, while the concentrations of $\mathrm{NO}_{2}{ }^{-}$and $\mathrm{NO}_{3}{ }^{-}$ were relatively low (Table 2). The maximum concentration of $\mathrm{NH}_{4}^{+}$was $149.3 \mathrm{mg} / \mathrm{L}$ and the maximum concentration of $\mathrm{PO}_{4}^{3-}$ was $34.1 \mathrm{mg} / \mathrm{L}$. Of all the 

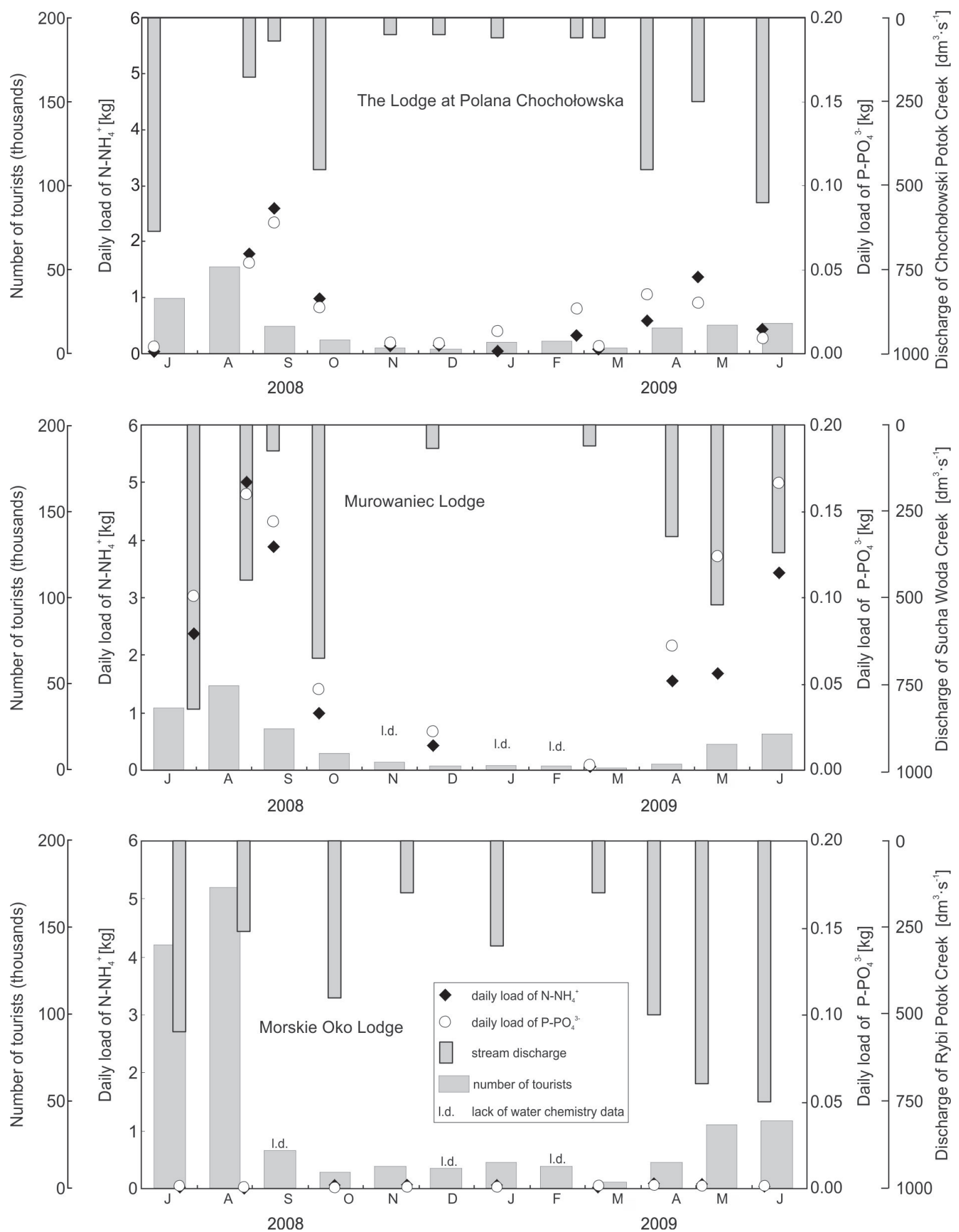

Figure 3 - Daily load of $\mathrm{N}-\mathrm{NH}_{4}^{+}$and $\mathrm{P}-\mathrm{PO}_{4}^{3-}$ disposed from treatment plants operated by selected tourist lodges in Tatra NP, discharge of the streams into which wastewater was disposed, and monthly number of tourists on the trails leading to the lodges.

lodges tested Murowaniec discharged the largest loads of $\mathrm{NH}_{4}^{+}$and $\mathrm{PO}_{4}^{3-}$. In the summer months, when discharge of the creek sometimes was very low, the largest loads of $\mathrm{NH}_{4}^{+}$and $\mathrm{PO}_{4}^{3-}$ were discharged into Sucha Woda Creek (Figure 3). The wastewater produced by Murowaniec Lodge marked the largest differences in the quality and quantity over the course of the year. Values of the variability coefficient for this lodge were higher than those for the remaining tourist lodges (Table 2). This was linked to larger variability in tourist traffic over the course of the year (Figure 3). Murowaniec Lodge is easy to reach in summer but difficult to reach in winter conditions.

High concentrations of $\mathrm{NH}_{4}^{+}$and $\mathrm{PO}_{4}^{3-}$ were the cause of the largest and statistically significant changes in water quality in Sucha Woda Creek downstream 
Table 3 - Significance of differences between the concentrations of biogenic ions upstream and downstream of wastewater discharge sites on the basis of the Wilcoxon test (showing only the statistically significant differences at $p<0.05$ ).

\begin{tabular}{|c|c|c|c|c|c|c|c|c|c|c|c|c|}
\hline & \multicolumn{3}{|c|}{ Chochołowski Potok Creek } & \multicolumn{3}{|c|}{ Sucha Woda Creek } & \multicolumn{3}{|c|}{ Rybi Potok Creek } & \multicolumn{3}{|c|}{ Roztoka Creek } \\
\hline & $T$ & $\mathbf{z}$ & $\mathbf{p}$ & $T$ & $\mathbf{Z}$ & $\mathbf{p}$ & $T$ & $\mathbf{Z}$ & $\mathbf{p}$ & $\begin{array}{ccc}T \\
T\end{array}$ & $\mathbf{Z}$ & $\mathbf{p}$ \\
\hline $\mathrm{NH}_{4}{ }^{+}$ & 0 & 2.934 & 0.003 & 0 & 2.666 & 0.008 & & & & & & \\
\hline $\mathrm{NO}_{2}^{-}$ & 0 & 2.366 & 0.018 & & & & & & & & & \\
\hline $\mathrm{NO}_{3}^{-}$ & & & & & & & & & & 0 & 2.201 & 0.028 \\
\hline $\mathrm{PO}_{4}^{3-}$ & 0 & 2.023 & 0.043 & 0 & 2.201 & 0.028 & & & & & & \\
\hline
\end{tabular}

from the point where wastewater was being discharged (Table 3). The concentrations of $\mathrm{NH}_{4}^{+}$and $\mathrm{PO}_{4}{ }^{3-}$ in Sucha Woda Creek were usually very low (less than 0.02 and 0.01 , respectively) before the point where the wastewater was being discharged. However, downstream from that point the concentration of $\mathrm{NH}_{4}^{+}$ reached a maximum of $0.80 \mathrm{mg} / \mathrm{L}$ and the concentration of $\mathrm{PO}_{4}^{3-}$ reached a maximum of $0.22 \mathrm{mg} / \mathrm{L}$ (Figure 4).

Morskie Oko Lodge in the catchment of Rybi Potok Creek

The amount of wastewater discharged into Rybi Potok Creek from the treatment plant at Morskie Oko proved to be difficult to estimate because of the cyclical operation of the treatment plant. The amount of discharged wastewater during eight different measurements performed in a 24-hour period was small compared to other lodges. Wastewater was being discharged at an average rate of $0.07 \mathrm{~L} / \mathrm{s}$. This is equivalent to about $6 \mathrm{~m}^{3}$ in a 24 -hour period. The average concentrations of $\mathrm{NH}_{4}{ }^{+}$and $\mathrm{PO}_{4}{ }^{3-}$ ions were 0.78 and $0.96 \mathrm{mg} / \mathrm{L}$, respectively, and were significantly lower than those in the wastewater being discharged from Polana Chochołowska and Murowaniec lodges. However, the average concentrations of $\mathrm{NO}_{2}^{-}$and $\mathrm{NO}_{3}{ }^{-}$ were relatively high: 1.44 and $5.55 \mathrm{mg} / \mathrm{L}$.

The concentrations of biogenic ions in Rybi Potok Creek, upstream and downstream from the wastewater discharge point, were usually low and differences were not statistically significant (Table 3). It is noteworthy that the concentrations of some biogenic ions, for example $\mathrm{NO}_{3}{ }^{-}$, were often higher upstream from the wastewater discharge point than downstream from it (Figure 4). This is most likely the result of large reserves of biogenic ions in the sediments of Żabie Oko (0.11 ha) and Małe Żabie Oko (0.02 ha), which are small pools of water created by the overflowing Rybi Potok Creek between the lodge and the wastewater discharge site. Wastewater from the mechanical treatment plant formerly operated by Morskie Oko Lodge used to be discharged into Rybi Potok Creek upstream from the two ponds.

The lodge in the Valley of Five Polish Ponds in the catchment of Roztoka Creek

The discharge of untreated wastewater from the lodge in the Valley of Five Polish Ponds into the Żleb Litworowy Couloir in the upstream part of the
Roztoka Creek catchment was a significant problem at the time when this research was conducted. The discharged wastewater initially flowed down a natural gutter, forming a small intermittent stream, and then it was joined by water discharged from the hydroelectric power station in the middle part of the couloir (on average $8 \mathrm{~L} / \mathrm{s}$ ). The freshwater and wastewater mixture then entered Roztoka Creek (Figure 2). In the years 2008-2009, water near the mouth of the Żleb Litworowy Couloir contained biogenic ions, mostly at concentrations several times higher than those in the water discharged from the power plant. For example, the corresponding concentrations of $\mathrm{NO}_{3}{ }^{-}$were 4.44 and $1.14 \mathrm{mg} / \mathrm{L}$, respectively, and the concentrations of $\mathrm{PO}_{4}^{3-}$ were 0.12 and $0.01 \mathrm{mg} / \mathrm{L}$, respectively. This was the result of mixing water from the upper part of the couloir, heavily polluted by wastewater, with clean water discharged by the power plant that had originated in the Przedni Staw Pond (Figure 2). A single sampling of surface water flowing down the middle part of the couloir returned relatively high concentrations of $\mathrm{NO}_{3}{ }^{-}$and $\mathrm{PO}_{4}{ }^{3-}(25.13,0.94 \mathrm{mg} / \mathrm{L}$, respectively). Discharging the freshwater and wastewater mix from the Żleb Litworowy Couloir (on average 15 L/s) caused statistically significant changes in the concentration of $\mathrm{NO}_{3}^{-}$(Table 3). The average concentration of $\mathrm{NO}_{3}{ }^{-}$in Roztoka Creek at points upstream from the couloir's mouth was $1.24 \mathrm{mg} / \mathrm{L}$, while downstream it was $1.39 \mathrm{mg} / \mathrm{L}$ (Figure 4). Biogenic compounds, which had accumulated for years in the ground in the couloir, would still be released from the ground and into the water supply for a long time, even after a treatment plant was built at the lodge.

\section{Discussion}

Wastewater discharge from wastewater treatment plants operated by tourist lodges in the Tatra Mountains in the years 2008-2009 caused significant changes in the concentration of some forms of biogenic ions in the streams into which they were discharged. The concentrations of $\mathrm{NH}_{4}^{+}$and $\mathrm{PO}_{4}^{3-}$ clearly increased in the streams into which wastewater was discharged directly from wastewater treatment plants (Sucha Woda, Chochołowski Potok). According to Chełmicki (2001), high concentration of $\mathrm{NH}_{4}^{+}$in stream water indicates that the source of poorly treated wastewater is near. The situation was different in the case of Roztoka Creek. Untreated wastewater was not discharged into 

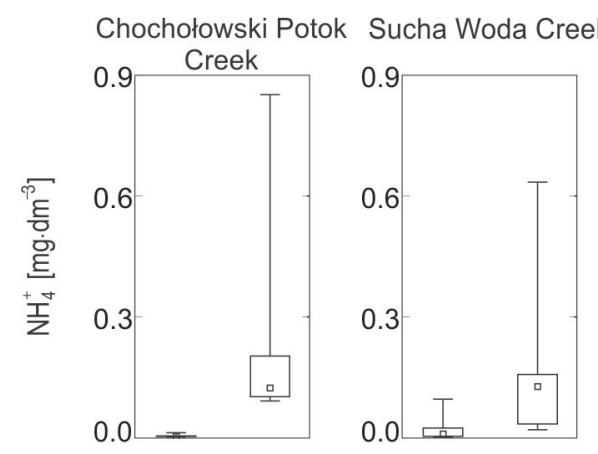

Rybi Potok Creek

Roztoka Creek
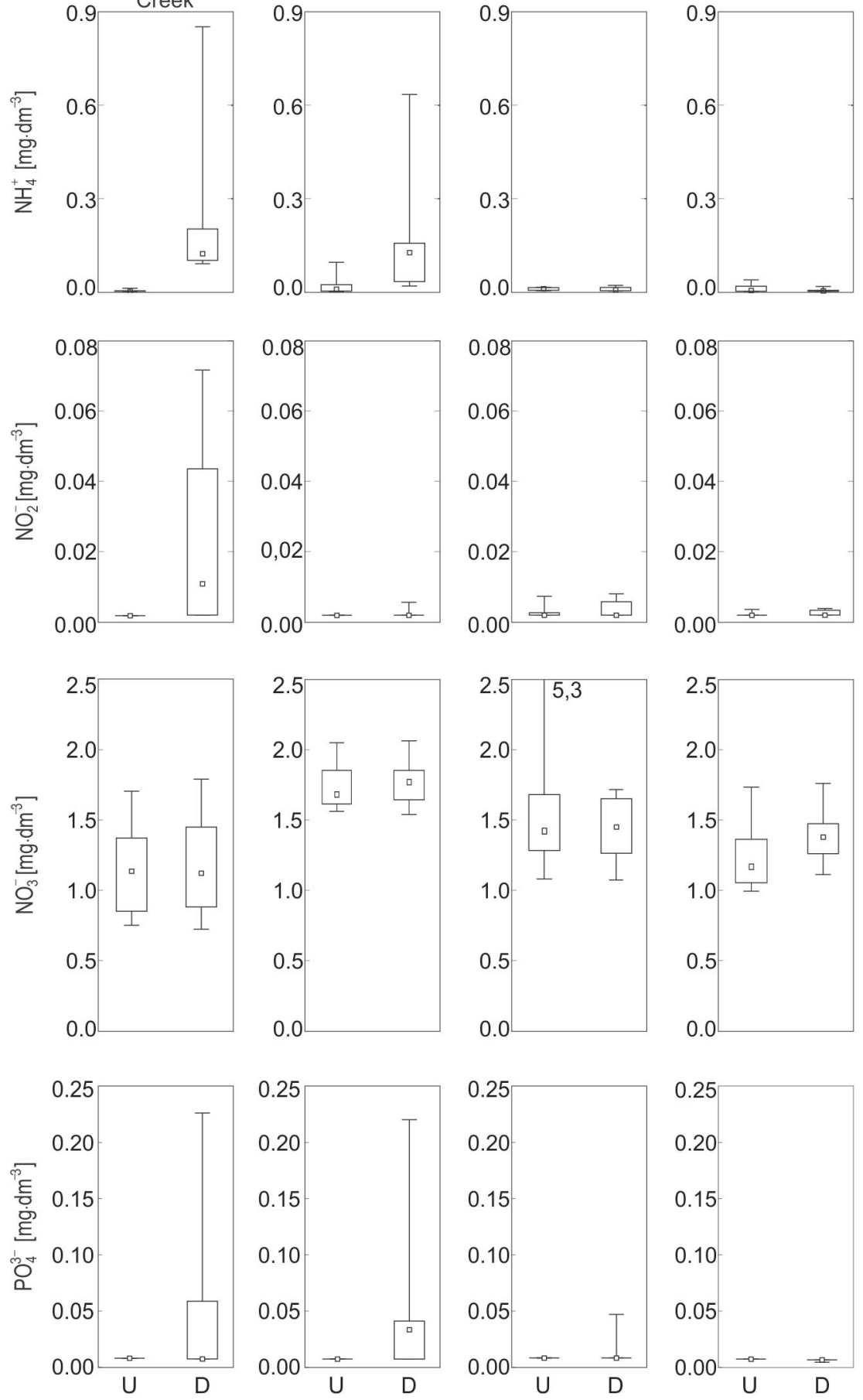

Figure 4 - Statistical characteristics of biogenic ion concentrations of stream water upstream (U) and downstream (D) from the wastewater discharge point (minimum, maximum, 25\% and $75 \%$ quantiles, median).

the stream directly, rather it flowed down a natural gutter, several hundred metres long, until it reached the stream. The concentration of $\mathrm{NO}_{3}^{-}$significantly increased in the stream. This indicated that oxidation of $\mathrm{NH}_{4}^{+}$and $\mathrm{NO}_{2}^{-}$to yield $\mathrm{NO}_{3}^{-}$had occurred. There was ample time for that process to take place, as the wastewater had to travel a long distance from the point of discharge until it reached Roztoka Creek.

The enrichment of water in both nitrogen and phosphorus in the case of Potok Chochołowski and
Sucha Woda was especially problematic, as it posed the threat of eutrophication, and therefore water pollution and lower water quality. Hydrobiological research conducted earlier in Rybi Potok (Kawecka 1977; Kownacki 1977) indicated that organisms living in the oligotrophic environment of Tatra mountain streams were especially sensitive to such changes. According to Kownacki (1996), the eutrophication of water caused, on the one hand, an expansion of some classes of invertebrates, such as Oligochaetes, Nematodes, Os- 
tracods, Cladocerans, Copepods, Gastropods, and Bivalves, and, on the other hand, also the dying out of Trichoptera.

According to the EU Water Framework Directive (2000), wastewater discharged into water bodies should not cause such changes, which would make proper functioning of water ecosystems impossible. This recommendation should be strictly complied with, especially in national parks, as the protection of these ecosystems is a statutory aim for the existence of the parks. In spite of the self-purification capacity of mountain streams, which has been demonstrated, for instance, by Ortiz et al. (2005), the decline of water quality in streams cannot be justified, even in short segments of their course.

The largest loads of biogenic ions that had their origin in wastewater entered Tatra mountain streams in the summer season. This was related to tourist impact in Tatra NP over the course of the year. Increased numbers of tourists in the summer months were the cause of the increase in wastewater production at tourist lodges in the park. Releasing a substantial load of biogenic ions into streams in the summer season created an ecological burden that is disadvantageous for two reasons. First, the streams' self-purification capacity was lower in the summer than in the winter. According to Hem (1985), the higher temperature of water in the summer decreased the degree of oxygen saturation in the water, which was responsible for the processes of self-purification (oxidation of organic compounds into inorganic compounds). Second, frequent low water levels in summer, with a smaller volume of water flowing in stream channels, meant less dilution of wastewater (Muscutt \& Whithers 1996; Rinella \& Janet 1998).

The water and wastewater management situation in Tatra NP has changed significantly since 2009, when this study was conducted, thanks to investment in modern infrastructure made by the owner of Tatra tourist lodges, the Polish Tourist and Sightseeing Society, which serves to protect the natural environment in Tatra NP (Ladygin 2011). As part of a project known as Green Hostels, co-funded by the European Union's Regional Development Fund, wastewater treatment plants functioning at tourist lodges in Polana Chochołowska and Murowaniec were fully modernized in 2010 and 2011. The wastewater was treated with UV radiation at the wastewater treatment plant at Murowaniec Lodge in order to kill disease-causing organisms. At the special request of Tatra NP management, the owner of the treatment plants was required to discharge wastewater of such quality that it would not cause changes in the established water cleanness class in the Sucha Woda Stream. In 2010 a new mechanical-biological wastewater treatment plant was opened at the lodge in the Valley of Five Polish Ponds, featuring a module used to chemically remove phosphorus. The lodge did not previously have a treatment plant (Siwek \& Biernacki 2015). The new plant was built thanks to financial support from the EkoFundusz Foundation, which, since 1992, has managed special funds that originated in a debt-for-investment exchange programme with the United States, France, Switzerland, Italy, Sweden, and Norway. This particular programme allowed the government of Poland to obtain a partial debt relief in exchange for investment in environmental protection (Zbaraszewski 2011).

It was very difficult to obtain good quality wastewater at treatment plants at mountain lodges, because the loads of wastewater were not evenly distributed over the course of a year. The loads of wastewater during the tourist season were large, which created a problem. Another problem was created when the amounts of wastewater were too small - outside the tourist season - as this posed a threat to biological life at the treatment plant. Mountain lodges, such as Murowaniec and Valley of Five Polish Ponds, were equipped with dual treatment systems (Siwek \& Biernacki 2015) so they could operate during the tourist season as well as beyond it. According to Lebersorger et al. (2010), 6\% of operators of refuges in the Alps had technical problems with wastewater treatment systems.

In spite of the fact that the water and wastewater management situation in Tatra NP significantly improved after 2010, it was still considered that transporting wastewater produced by treatment plants already operating at many tourist lodges out of the national park and to a treatment plant in Zakopane may be an effective method for protecting the park's water quality. This would be a good solution, considering that wastewater purification was not always sufficient and that the requirements for water quality protection in the mountain national park are especially strict. Transporting wastewater out of the national park may be an effective method of protecting water quality, assuming that the tanks collecting the wastewater were emptied frequently enough. This was also recommended in regulations on the protection of water quality at Scottish Cairngorms NP (Water Resources 2010). Research carried out in the Austrian Alps by Becker \& Cord (1993) indicates that transporting wastewater from mountain refuges to treatment plants in the valleys is generally advantageous. However, according to Rauch \& Becker (2000), this option is often not feasible for economic and technical reasons. In the case of most lodges in Tatra NP, this method could be used - most of them can be reached by off-road vehicles like tractors. This method proved effective in protecting the quality of water in Potok Kościeliski Creek (Western Tatras, Poland), into which wastewater used to be discharged from the wastewater treatment plant operated at Ornak Lodge (Tatra NP - unpublished data).

\section{Conclusions}

Mountain tourist lodges in Tatra NP, even those equipped with mechanical and biological wastewater treatment plants, have been an important source of 
pollution for Tatra mountain streams for many years. This was confirmed by the research conducted in the years 2008-2009. Wastewater from wastewater treatment plants was poorly purified, which became evident through high concentrations of $\mathrm{NH}_{4}^{+}$and $\mathrm{PO}_{4}^{3-}$. The ion load was so great that, in spite of favourable dilution conditions, it caused significant changes in the concentration of these ions in mountain streams at points downstream from wastewater discharge sites. The streams in Tatra NP are especially threatened by eutrophication from the simultaneous influx of nitrogen and phosphorus. The largest loads of biogenic ions carried with wastewater reached the park's streams from May until September. This is related to the large number of tourists visiting the Tatra Mountains during that period. It should be noted that there was one tourist lodge in the national park at the time which discharged untreated wastewater into mountain stream water. In the years 2010-2011, thanks to European Union support, the water and wastewater management situation in Tatra NP improved significantly. The mechanical and biological wastewater treatment plants at Murowaniec and Polana Chochołowska tourist lodges were completely modernized and a new one built at the lodge in the Valley of Five Polish Ponds. While we appreciating the effort put into reducing the unfavourable influence of tourism on water quality in the Tatra Mountains, we believe that the only method guaranteeing the protection of water quality is transporting wastewater to treatment plants outside the national park. It is the most effective and reliable method of protecting the oligotrophic mountain waters from pollution.

\section{Acknowledgement}

The research project was funded by the University of Physical Education in Cracow (Project 238/ ITiR/2008) and by the Jagiellonian University in Cracow, Institute of Geography and Spatial Management.

\section{References}

Allan, J.D. 1995. Stream ecology. Structure and function of running waters. London.

Becker, W. \& G. Cord 1993. Design and results of small wastewater treatment plants with no or little energy input in mountainous regions. In: Ødegaard, $\mathrm{H}$. (ed.), Proceedings of the 2nd Specialized Conference on Small Wastewater Treatment Plants: 67-82. Trondheim.

Bombówna, M. 1977. Biocenosis of a high mountain stream under the influence of tourism. Chemistry of the Rybi Potok waters and the chlorophyll content in attached algae and seston in relation to the pollution. Acta Hydrobiologica 19(3): 243-255.

Chełmicki, W. 2001. Water. Resources, degradation, protection. Warszawa.

Cilimburg, A., C. Monz \& S. Kehoe 2000. Wildland recreation and human waste: a review of problems, practices, and concerns. Environmental Management 25(6): 587-598.

Eagles, P.F.J. \& S.F. McCool 2002. Tourism in national parks and protected areas: Planning and management. CABI Publishing-CAB International. Wallingford.

Eagles, P.F.J., S.F. McCool \& C.D. Haynes 2002. Sustainable tourism in protected areas: Guidelines for planning and management. IUCN-The World Conservation Union. Cambridge.

Ells, M.D. \& C.A. Monz 2011. The consequences of backcountry surface disposal of human waste in an alpine, temperate forest and arid environment. Journal of Environmental Management 92: 1334-1337.

Flack, J.E., A.J. Medine \& K.J. Hansen-Bristow 1988. Stream water quality in a mountain recreation area. Mountain Research and Development 8(1): 11-22.

Hem, J.D. 1985. Study and interpretation of the characteristics of natural water. Alexandria.

Kawecka, B. 1977. Biocenosis of a high mountain stream under the influence of tourism. Attached algal communities in the stream Rybi Potok (the High Tatra Mts, Poland) polluted with domestic sewage. Acta Hydrobiologica 19(3): 271-292.

Kawecka, B. 1993. Ecological characteristics of sessile algal communities in streams flowing from the Tatra Mountains in the area of Zakopane (southern Poland) with special consideration of their requirements with regard to nutrients. Acta Hydrobiologica 35(4): 295-306.

Kownacki, A. 1977. Biocenosis of a high mountain stream under the influence of tourism. The bottom fauna of the stream Rybi Potok (the High Tatra Mts, Poland). Acta Hydrobiologica 19(3): 293-312.

Kownacki, A. 1996. Fauna of the streams. In: Mirek, M. (ed.), Nature of the Tatra National Park: 555573. Kraków-Zakopane.

Kurek, W. 2007. Mountain national parks in Europe (selected problems). In: Pociask-Karteczka, J., A. Matuszyk \& P. Skawiński (eds.), The state and perspectives of tourism development in Tatra National Park: 35-46. Kraków-Zakopane.

Lebersorger, S., N. Weissenbacher, E. Mayr \& C. Aschauer 2010. Waste management in mountain refuges - an integrated evaluation. Waste Management \& Research 29(5): 549-557.

Li, W., Q. Zhang, C. Liu \& Q. Xue 2006. Tourism's impacts on natural resources: a positive case from China. Environmental Management 38: 572-579.

Life98 ENV/A/000547 2000. Available at: http:// ec.europa.eu/environment/life/project/Projects/index.cfm? fuseaction=search.dspPage\&n_proj_id $=910$. (accessed 14.10.2015)

Ladygin, Z. 2011. W schroniskach bardziej ekologicznie. Biuletyn TPN 6(21): 7-10. [In Polnish]

Łajczak, A. 1996. Hydrology. In: Mirek, M. (ed.), Nature of the Tatra National Park: 169-196. KrakówZakopane.

McDonald, A.T., P.J. Chapman \& K. Fukasawa 2008. The microbial status of natural waters in a pro- 
tected wilderness area. Journal of Environmental Management 87: 600-608.

Mirek, Z. 1996. Anthropogenic threats and changes of the nature. In: Mirek, M. (ed.), Nature of the Tatra National Park: 595-617. Kraków-Zakopane.

Muscutt, A.D. \& J.A. Whithers 1996. The phosphorus content of rivers in England and Wales. Water Research 30(5): 1258-1268.

Oleksynowa, K. \& T. Komornicki 1996. Chemical composition of the water. In: Mirek, M. (ed.), Nature of the Tatra National Park: 197-214. Kraków-Zakopane.

Ortiz, J.D., E. Martı' \& M. Angels Puig 2005. Recovery of the macroinvertebrate community below a wastewater treatment plant input in a Mediterranean stream. Hydrobiologia 545: 289-302.

Pickering, C.M., J. Harrington \& G. Worboys 2003. Environmental impacts of tourism on the Australian Alps Protected Areas. Mountain Research and Development 23 (3): 247-254.

Rauch, W. \& W. Becker 2000. Waste sludge disposal in extreme alpine environments. Waste Management and Research 18: 33-40.

Rinella, F.A. \& M.L. Janet 1998. Seasonal and spatial variability of nutrients and pesticides in streams of the Willamette Basin, Oregon, 1993-95. Portland.

Silsbee, D.G. \& G.L. Larson 1982a. Water quality of streams inthe Great Smoky Mountains National Park. Hydrobiologia 89: 97-115.

Silsbee, D.G. \& G.L. Larson 1982b. Bacterial water quality: springs and streams in the Great Smoky Mountains National Park. Environmental Management 6(4): 353-359.

Siwek, J., B. Rzonca, B. Jaśkowiec, J. Plenzler \& E. Płaczkowska 2013. Natural factors affecting the chemical composition of water in the catchment of Wołosatka Stream (High Bieszczady Mts.). In: Kozak, J., K. Ostapowicz, A. Bytnerowicz \& B. Wyżga (eds.), The Carpathians: integrating nature and society towards sustainability: 151-159. Berlin, Heidelberg.

Siwek, J.P. \& W. Biernacki 2015. Wpływ ścieków odprowadzanych ze schronisk turystycznych na stężenia związków biogennych w potokach - odbiornikach tych ścieków na terenie Tatrzańskiego Parku Narodowego (lata 2008-2009). Gospodarka Wodna 7: 202-209. [In Polnish]

Starzecka, A. 1977. Biocenosis of a high mountain stream under the influence of tourism. Bacteria as an index of water pollution of the Rybi Potok stream. Acta Hydrobiologica 19(3): 257-270.

Sun, D. \& D. Walsh 1998. Review of studies on environmental impacts of recreation and tourism in
Australia. Journal of Environmental Management 53(4): 323-338.

U.S. National Park Service 2012. https://irma. nps.gov/Stats/SSRSReports/National\%20Reports /Annual $\% 20$ Park $\% 20$ Ranking $\% 20$ Report $\% 20$ (1979\%20-\%20Last $\% 20$ Calendar\%20Year) (accessed $18 / 08 / 2012)$

Tatra National Park 2012. Available at: http:// tpn.pl/filebrowser/files/Bilety_2012.pdf (accessed 20/10/2015)

Varness, K.J., R.E. Pacha \& R.F. Lapen 1978. Effects of dispersed recreational activities on the microbiological quality of forest surface water. Applied and Environmental Microbiology 36 (1): 95-104.

Water Framework Directive 2000. Directive 2000/60/EC of the European Parliament and of the Council of 23 October 2000 establishing a framework for community action in the field of water policy.

Water Resources 2010. Planning in the Cairngorms National Park 2010. Cairngorms National Park. Grantown-on-Spey.

Zbaraszewski, W. 2011. Rola fundacji Eko-Fundusz w finansowaniu ochrony środowiska w Polsce. Folia Pomeranae Universitatis Technologiae Stetinensis 291(65): 175-184. [In Polnish]

Żelazny, M. 2012. Spatiotemporal variability of physical and chemical characteristics of waters of the Tatra National Park. Kraków.

\section{Authors}

\section{Joanna Paulina Siwek}

is a hydrologist at the Jagiellonian University in Krakow. Her research interests are hydrochemical processes in catchments and the human impact on the river water and groundwater quality. Jagiellonian University, Institute of Geography and Spatial Management, Department of Hydrology. ul. Gronostajowa 7, 30-387 Kraków, Poland. Corresponding author: email: joanna.siwek@uj.edu.pl

\section{Wojciech Biernacki}

is a geographer, lecturer in the Department of Natural Sciences at the University of Physical Education in Cracow. He studies the influence of tourism on the state of the environment in protected areas. University of Physical Education, Faculty of Tourism and Leisure, Department of Natural Sciences. Al. Jana Pawła II 78, 31-571 Kraków, Poland 